\title{
IMPLEMENTASI KURIKULUM 2013 DALAM PEMBELAJARAN BAHASA INDONESIA DI DALAM DAN LUAR NEGERI (STUDI KASUS PEMBELAJARAN TEKS BIOGRAFI DI SMA NEGERI 1 SURAKARTA DAN SEKOLAH INDONESIA SINGAPURA)
}

\author{
Mutiatus Sholihah, Kundharu Saddhono, Atikah Anindyarini \\ Universitas Sebelas Maret \\ Surel:sholihahmutiatus@gmail.com
}

\begin{abstract}
: this research aims to explain: (1) preparation, implementation and assessment of learning, (2) problems encountered in the learning process, and (3) efforts made to overcome problems in the Indonesian Language learning process with Curriculum 2013 in the Class X in SMA N 1 Surakarta and Sekolah Indonesia Singapura.This research is a case study research. Samples in this research are the students of class X IPA III, and X IPA I SMA Negeri 1 Surakarta and students of class X IPA and X IPS Sekolah Indonesia Singapura.The sampling technique is purposive sampling.Technique of data collecting done by observation, interview, and document analysis.Data analysis technique is an interactive analysis model.The result of this research are description about: (1) lesson planning, (2) lesson implementation is not in accordance yet with RPP previously written by the teacher, (3) the assessment of learning has adopted an authentic approach according to Permendikbud Number 23 of 2016, (4) the problems faced are the inadequacy of the RPP with the latest regulation, limited learning resources, limited time and place, limited facilities, limited educators, difficulties in understanding and remembering material presented by teachers, limited knowledge and readiness of teachers, low understanding of Curriculum 2013 to student, and low student learning motivation, (5) the efforts undertaken are the school and teachers trying to follow the development related to the Curriculum 2013.
\end{abstract}

Keywords:implementation, Indonesian Language Learning, Curriculum 2013, biography text

\begin{abstract}
Abstrak: Penelitian ini bertujuan untuk menjelaskan: (1) persiapan, pelaksanaan dan penilaian pembelajaran teks biografi, (2) masalah yang dihadapi dalam proses pembelajaran, dan (3) upaya yang dilakukan untuk mengatasi masalah dalam proses pembelajaran. Penelitian ini merupakan penelitian studi kasus. Sumber data yang digunakan berupa peristiwa, informan, dan dokumen. Sampel penelitian adalah siswa kelas X IPA III, dan X IPA I SMA Negeri 1 Surakarta dan siswa kelas X IPA dan X IPS Sekolah Indonesia Singapura. Teknik pengumpulan data dilakukan dengan observasi, wawancara, dan analisis dokumen. Uji validitas data yang digunakan adalah triangulasi sumber data, triangulasi metode, dan review informan. Teknik analisis data adalah model analisis interaktif. Hasil penelitian ini adalah deskripsi mengenai: (1) perencanaan pembelajaran, (2) pelaksanaan pembelajaran, (3) penilaian pembelajaran telah menerapkan pendekatan autentik, (4) masalah yang dihadapi guru dalam penyusunan RPP, keterbatasan sumber belajar, keterbatasan waktu dan tempat, rendahnya pemahaman Kurikulum 2013 pada siswa, dan rendahnya motivasi belajar siswa, (5) upaya yang dilakukan yaitu pihak sekolah dan guru berupaya untuk mengikuti perkembangan terkait Kurikulum 2013, penyusunan sistem presensi, optimalisasi sumber, fasilitas, dan media.
\end{abstract}

Kata kunci: pembelajaran bahasa Indonesia, teks biografi, Kurikulum 2013

BASASTRA Jurnal Bahasa, Sastra, dan Pengajarannya 


\section{PENDAHULUAN}

Layaknya kompas, kurikulum memerankan peranan yang penting dalam mengorganisasikan, mengarahkan, dan membimbing kegiatan pembelajaran (Dominggus, Huliselan \& Takaria, 2016).The curriculum is like a compass in guiding the ship to sail the world of education. Like a compass, curriculum playes an important role in organizing, directing, and guiding the learning activities.

Murray Print (1993) dalam Yani (2014: 5) kurikulum adalah semua kesempatan belajar yang direncanakan untuk siswa di sekolah dan institusi pendidikan lainnya. Kurikulum juga dapat dimaknai sebagai rancangan pengalaman yang akan diperoleh siswa ketika kurikulum tersebut diimplementasikan. Yani, (2014: 2) kurikulum sering dijadikan pusat dari sistem penggerak komponen pendidikan lainnya. Karena itu timbul pemahaman kurikulum diartikan sebagai kumpulan dari berbagai pengalaman yang akan dipelajari siswa. Agar siswa sukses menguasai berbagai pengalaman itu, dibutuhkan berbagai sumber belajar, guru, sarpras, anggaran, kebijakan, dan sistem pengelolaan yang baik. Dari pernyataan tersebut dapat dipahami bahwa kurikulum merupakan sebuah sistem yang mendasari segala aspek kegiatan pembelajaran.

Kurikulum 2013 adalah kurikulum yang diterapkan mulai tahun ajaran 2013/2014 dan berasal dari pengembangan kurikulum sebelumnya, yaitu Kurikulum Berbasis Kompetensi (KBK) dan Kurikulum Tingkat Satuan Pendidikan (KTSP). Pada kurikulum ini aspek softskill dan hardskill lebih ditekankan kepada siswa dengan tujuan untuk meningkatkan dan menyeimbangkan kompetensi sikap, keterampilan, dan pengetahuan siswa (Fadlillah, 2014: 16-17). Tema Kurikulum 2013 adalah menghasilkan insan Indonesia yang produktif, kreatif, inovatif, afektif, melalui penguatan sikap, keterampilan dan pengetahuan yang terintegrasi. Guna mewujudkan hal tersebut, guru dituntut untuk lebih profesional merancang pembelajaran afektif, dan bermakna (menyenangkan), mengorganisasikan pembelajaran, memilih 
pendekatan pembelajaran yang tepat, menentukan prosedur pembelajaran dan pembentukan kompetensi secara efektif.

Salah satu upaya yang bisa dilakukan penyelenggara pendidikan guna mewujudkan kesuksesan pembelajaran saat ini adalah dengan penerapan Kurikulum 2013. Orientasi dari Kurikulum 2013 adalah tercapainya kompetensi yang seimbang antara sikap (attitude), keterampilan (skill), dan pengetahuan (knowledge) siswa (Majid, 2014: 1).Meskipun penerapan Kurikulum 2013 telah dilaksanakan secara bertahap sejak tahun ajaran 2013/2014 (Juli 2013), beberapa pihak di lingkungan pendidikan sampai saat ini masih menganggap Kurikulum 2013 adalah hal yang relatif baru (Mulyasa, 2014: 3). Bahkan ada pula instansi pendidikan yang sampai saat ini belum menerapkan Kurikulum 2013 dalam kegiatan pembelajaran.

Memasuki tahun ajaran 2016/2017, pemerintah meluncurkan kurikulum revisi baik untuk sekolah dasar maupun menengah. Kurikulum tersebut merupakan hasil dari proses evaluasi penerapan Kurikulum 2013 sejak mulai diterapkan. Kurikulum baru tersebut tetap menggunakan nama Kurikulum 2013, atau lebih dikenal masyarakat dengan Kurikulum 2013 Edisi Revisi Tahun 2016.Adapun elemen-elemen utama yang menjadi indikator perubahan Kurikulum 2013 dapat disebutkan seperti pendapat Kurniasih \& Berlin (2017c: 19)dan dalam Kompasiana.com seperti berikut ini; (1) perbaikan dan penyelarasan pada Kompetensi Inti (KI) dan Kompetensi Dasar (KD) pada mata pelajaran beserta analisisnya terhadap Standar Kompetensi Lulusan (SKL), (2) perubahan dan perbaikan materi, serta urutan materi pada Buku Guru (BG) dan Buku Siswa (BS), (3) adanya penegasan dalam implementasi pendekatan saintifik dalam pembelajaran, yaitu bukan hanya diajarkan dan dijelaskan oleh guru namun juga harus dipraktekkan kepada siswa, (4) model pembelajaran Kurikulum 2013 tidak hanya sebatas tiga model saja yang selama ini dikenalkan, yaitu pembelajaran berbasis projek (project based learning), pembelajaran berbasis masalah (problem based learning), dan pembelajaran penemuan (discovery/inquiry) namun guru bebas memilih model yang sesuai dengan karakteristik materi pelajaran, kebutuhan, situasi, dan kondisi, (5) penyederhanaan aspek penilaian otentik 
siswapada pada KI-I dan KI-II, pada skema yang baru ini penilaian sosial dan keagamaan/spiritualsiswa cukup dilakukan oleh guru mata pelajaran PPKn dan Agama/Budi Pekerti, sedangkan guru mata pelajaran hanya menilai aspek sikap umum berupa perilaku peserta didik dalam proses pembelajaran akademik sesuai bidang yang diajarkan.

Sesuai dengan Permendikbud Nomor 22 Tahun 2016 tentang Standar Proses Pendidikan Dasar dan Menengah, proses implementasi sebuah pembelajaran pada satuan pendidikan diselenggarakan secara interaktif, inspiratif, menyenangkan, menantang, memotivasi siswa untuk berpartisipasi aktif, serta memberikan ruang yang cukup bagi prakarsa, keativitas, dan kemandirian sesuai dengan bakat, minat, dan perkembangan fisik serta psikologis siswa. Untuk itu setiap satuan pendidikan wajib melakukan perencanaan pembelajaran, pelaksanaan proses pembelajaran, serta penilaian proses pembelajaran untuk meningkatkan efisiensi dan efektivitas ketercapaian kompetensi lulusan.

Demi terselenggaranya kesuksesan implementasi Kurikulum 2013, peranan guru dalam kegiatan pembelajaran sangatlah penting. Guru sebagai penggerak kegiatan siswa dalam kelas harus memastikan bahwa kegiatan pembelajaran di sekolah telah sesuai dengan standar pendidikan, baik dalam persiapan, pelaksanaan, dan penilaian. Dalam pelaksanaannya, guru tidak akan mungkin terlepas dari sebuah hambatan atau masalah. Adanya hambatan yang dihadapi tentu semakin melatih guru untuk dapat mencari solusi, sekaligus dapat lebih memperbaiki kualitas pembelajaran dengan menggunakan Kurikulum 2013 khususnya pembelajaran Bahasa Indonesia dengan Kurikulum 2013 Edisi Revisi.

Perlu diketahui bahwa sekolah yang telah menerapkan Kurikulum 2013 termutakhir ini bukan hanya sekolah Indonesia yang berada di Indonesia saja, namun juga sekolah Indonesia yang berada di luar negeri.Sekolah Indonesia Luar Negeri (SILN) adalah sekolah yang didirikan oleh Depdiknas dimana sekolahsekolah tersebut berada di wilayah akreditasi kerja Kedutaan Besar Republik Indonesia (KBRI) ataupun Konsulat Jendral Republik Indonesia (KJRI) dibawah bimbingan Atase Pendidikan Nasional(Nurjanah, 2015: 2). Sekolah Indonesia yang berada di dalam maupun luar negeri yaitu SILN, yang masih di bawah 
Kementrian Pendidikan dan Kebudayaan Republik Indonesia, beberapa dari sekolah tersebut merupakan sekolah yang pada proses penyelenggaraan pendidikannya menerapkan Kurikulum 2013. Salah satu sekolah dalam negeri yang menggunakan Kurikulum 2013 sejak tahun ajaran 2013/2014 hingga saat ini adalah SMA Negeri 1 Surakarta, sedangkan salah satu SILN yang juga telah menerapkan Kurikulum 2013 adalah Sekolah Indonesia Singapura(SIS). Sekolah ini mulai menyelenggarakan penerapan Kurikulum 2013 pada semester gasal di tahun ajaran 2014/2015 kemudian dihentikan sejenak dan mulai menggunakan Kurikulum 2013 lagi setelah adanya Revisi dari Kemendikbud.

Penelitian di sekolah dalam negeri dan SILN (SMA Negeri 1 Surakarta dan Sekolah Indonesia Singapura) dalam konteks pembelajaran Bahasa Indonesia dengan Kurikulum 2013 ini diperlukan, melihat adanya alasan mengenai kondisi SIS yang berada di luar negeri atau luar lingkungan masyarakat Indonesia sehingga mengharuskan sebuah adaptasi tersendiri. Selain itu pula adanya alasan mengenai posisi SMA Negeri 1 Surakarta yang merupakan salah satu sekolah percontohan dari pelaksanaan Kurikulum 2013 di Indonesia. Hal yang dapat disoroti dalam penelitian ini adalah bertujuan untuk mendeskripsikan pelaksanaan pembelajaran Bahasa Indonesia dengan Kurikulum 2013 Edisi Revisi Tahun 2016 utamanya dalam proses pembelajaran (meliputi perencanaan, pelaksanaan, dan penilaian), hingga identifikasi masalah yang timbul serta solusi yang dilakukan dalam mengatasi masalah pada kegiatan pembelajaran di sekolah dalam dan luar negeri.

\section{METODE PENELITIAN}

Penelitian ini merupakan jenis penelitian studi kasus dengan pendekatan deskriptif kualitatif. Kualitatif berarti sesuatu yang berkaitan dengan aspek kualitas nilai atau makna yang terdapat dibalik fakta dan hanya dapat dijelaskan melalui linguistik bahasa atau kata-kata (Gunawan, 2015: 82).

Penelitian dilaksanakan mulai bulan Januari 2017 hingga Januari 2018. Sumber data dalam penelitian ini meliputi data primer dan sekunder. Data primer berupa peristiwa pembelajaran, narasuber/informan (guru mata pelajaran dan 
siswa), serta dokumen/arsip berupa perangkat pembelajaran yang digunakan dalam kegiatan pembelajaran (silabus, RPP, instrumen penilaian). Sedangkan data sekunder berupa referensi buku dan undang-undang tentang Kurikulum 2013, referensi mengenai data sekolah, dan jurnal penelitian terdahulu terkait implementasi Kurikulum 2013 dalam pembelajaran Bahasa Indonesia.

Teknik pengambilan sampel yang digunakan dalam penelitian adalah teknik purposive sampling. Teknik pengumpulan data yang digunakan dalam penelitian ini diantaranya teknik catat dan rekam untuk observasi/pengamatan dan wawancara, serta teknik analisis dokumen. Untuk menguji keabsahan/validitas data dalam penelitian ini menggunakan teknik triangulasi sumber data, triangulasi metode, dan review informan, sedangkan analisis data menggunakan model analisis interaktif yang meliputi pengumpulan data, reduksi data, penyajian data, dan penarikan kesimpulan.

\section{HASIL PENELITIAN DAN PEMBAHASAN}

Adanya perbaikan Kurikulum 2013 Tahun 2016 secara langsung mempengaruhi hal-hal kecil hingga besar dalam dunia pembelajaran. Hal yang sangat disoroti dalam pembaharun ini tentu mengenai perencanaan, pelaksanaan, dan penilaian pembelajaran karena ranah tersebut merupakan sasaran dari pemutakhiran Kurikulum oleh Pemerintah. Guru selaku aktor dalam kegiatan pembelajaran dituntut untuk terampil dalam memahami, menyusun dan mengimplementasikan konsep Kurikulum 2013 terbaru utamanya dalam pembelajaran Bahasa Indonesia. Kemampuan guru dalam menerapkan pendekatan, metode, media, model, pembelajaran dan menyesuaikannya berdasarkan karakteristik siswa sangat diperlukan guna mencapai tujuan pembelajaran yaitu membentuk siswa yang bermoral, berkompetensi, dan penuh kreatifitas.

Ditinjau dari urutan pelaksanaan pebelajaran pada Permendikbud Nomor 22 Tahun 2016 yang meliputi kegiatan pendahuluan, inti, penutup tentu tidak akan lepas dari sebuah permasalahan. Kendala tersebut bisa saja dihadapi siswa maupun guru hingga sekolah selaku penyelenggara pendidikan. Berdasarkan hasil 
penelitian studi kasus di SMA Negeri 1 Surakarta dan Sekolah Indonesia Singapura maka Peneliti menemukan beberapa temuan yang menjadi ciri khas pembelajaran di sekolah-sekolah tersebut. Berikut pembahasan mengenai temuan penelitian yang menjadi ciri pembelajaran Bahasa Indonesia dengan Kurikulum 2013 Edisi Revisi kelas X di SMA Negeri 1 Surakarta dan Sekolah Indonesia Singapura.Perencanaan Pembelajaran Teks Biografi dengan Kurikulum 2013 kelas X di SMA Negeri 1 Surakarta dan Sekolah Indonesia Singapura

Menurut Masjid (2014: 15) perencanaan pembelajaran adalah kegiatan menyusun langkah-langkah yang akan dilaksanakan untuk mencapai tujuan yang telah ditentukan. Sedangkan dalam Permendikbud Nomor 22 Tahun 2016 perencanaan pembelajaran dirancang dalam bentuk Silabus dan Rencana Pelaksanaan Pembelajara (RPP) yang mengacu pada standar isi.

Dalam penelitian ini peneliti menemukan bahwa kegiatan persiapan pembelajaran yang dilakukan oleh guru mata pelajaran Bahasa Indonesia (ES) di SMA Negeri 1 Surakarta dan guru mata pelajaran Bahasa Indonesa (IK)di Sekolah Indonesia Singapura dimulai dengan pengkajian silabus. Silabus yang digunakan oleh ES dan IK merupakan Silabus Kurikulum 2013 Edisi Revisi yang didapat dengan mengunduh dari sumber media online, selanjutnya guru mengembangkan silabus menjadi RPP.

Berdasarkan hasil wawancara dalam CLHW-5 peneliti menemukan bahwa mekanisme penyusunan perencanan pembelajaran di SMA Negeri 1 Surakarta setelah pengkajian silabus adalah melakukan kegiatan lokakarya dan seminar yang dihadiri oleh para guru. Kegiatan ini berfungsi untuk memberikan sosialisasi mengenai penyusunan perencaraan pembelajaran yang mencakup Promes, RPP, serta pengumuman tentang tenggat waktu bagi guru untuk menyusun dan mengumpulkan RPP sebelum pembelajaran satu semester dimulai. Adanya alokasi waktu untuk periodisasi penyusunan RPP di SMA Negeri 1 Surakarta ini menjadikan guru lebih terbantu dalam membagi waktu dan lebih terkondisi dalam menyusun perencanaan pembelajaran. Setelah kegiatan sosialisasi, guru dipersilakan untuk memulai menyusun RPP sesuai dengan sistematika dari Pemerintah.Namun berdasarkan hasil analisis CLHA-5 oleh peneliti, ditemukan 
RPP yang disusun ES masih berkiblat pada Kurikulum 2013 lama, hal ini ditunjukkan dengan penulisan Kompetensi Dasar, dan Kegiatan Inti Pembelajaran dalam RPP.

Di Sekolah Indonesia Singapura kegiatan perencanaan pembelajaran kurang terkondisi dengan baik. Kenyataan ini diperoleh peneliti berdasarkan CLHW-1, hasil wawancara peneliti dengan IK yang menyatakan bahwa guru Bahasa Indonesia di Sekolah Indonesia Singapura kurang berkoordinasi dalam menyusun RPP, sehingga suatu waktu guru terpaksa tidak menyusun RPP. Di sekolah tersebut tidak ada alokasi waktu untuk periodisasi penyusunan RPP secara pasti. Kegiatan perencanaan hanya meliputi pengkajian silabus yang baru, selanjutnya guru akan mengganti komponen-komponen dalam RPP lama dengan menyesuaikan komponen-komponen baru seperti dalam silabus yang baru, misalnya seperti penulisan Kompetensi Dasar.

Dari pernyataan di atas dapat disimpulkan bahwa kegiatan perencanaan pembelajaran di SMA Negeri Surakarta dan Sekolah Indonesia Singapura belum sepenuhnya memenuhi standar, meskipun telah menggunakan silabus Kurikulum 2013 terbaru, namun untuk penyusunan RPP masih terdapat beberapa kesalahan penulisan dan tidak sesuai dengan konsep RPP dalam Permendikbud Nomor 22 Tahun 2016.

\section{Pelaksanaan Pembelajaran Teks Biografi dengan Kurikulum 2013 kelas}

\section{X di SMA Negeri 1 Surakarta dan Sekolah Indonesia Singapura}

Pelaksanaan pembelajaran merupakan implementasi dari RPP, menurut Permendikbud Nomor 22 Tahun 2016 dalam pembelajaran dengan Kurikulum 2013 terdapat hal-hal yang harus dipenuhi dalam pelaksanaan proses pembelajaran yaitu:

(1) Alokasi waktu jam tatapmuka di setiappembelajaran

(2) Rombonganbelajar

(3) Tersedianyabukutekspelajaran yang digunakanuntukmeningkatkanefisiensidanefektivitaspembelajaran

(4) Pengelolaankelasdanlaboratorium

Adapun dalam kegiatan pembelajaran terdapat tiga kegiatan. Kegiatan pertama adalah kegiatan pendahuluan, kegiatan inti dan kegiatan penutup. Ketiga 
kegiatan tersebut tersusun menjadi satu dalam suatu kegiatan pembelajaran dan tidak dapat dipisah-pisahkan.

\section{a. Kegiatan Pendahuluan}

Berdasarkan hasil pengamatan peneliti dalam CLHO-3, dan CLHO-4 kegiatan pendahuluan yang dilakukan ES di SMA Negeri 1 Surakarta dimulai dengan mengucap salam, selanjutnya memberikan pemahaman kepada siswa tentang materi apa yang akan disampaikan pada pertemuan tersebut. selain itu ES juga mengaitkan materi pada pertemuan sebelumnya, dengan cara ES mengajak siswa untuk mereview materi sehingga siswa ingat kembali. Namun dalam kegiatan ini ES masih jarang sekali melakukan tindakan yang sifatnya membangun semangat dan motivasi siswa, sebaliknya ES masih terfokus pada penyampaian Kompetensi Dasar yang akan dicapai saja. Selain itu alokasi waktu selama kegiatan pendahuluan juga tidak sesuai dengan RPP yang telah ditulis oleh ES sebelumnya.

Kegiatan pendahuluan di Sekolah Indonesia Singapura berdasarkan CLHO-5 dan CLHO-6 dilakukan IK menekankan pada penumbuhan minat dan motivasi siswa. IK selalu membuka kelas dengan percakapan ringan dengan siswa. Dengan menggunakan bahasa nonformal, IK mengaku hal tersebut digunakan untuk membentuk ikatan antara guru dan siswa, sehingga lebih akrab dan mudah dalam berkomunikasi selama pembeljaran. Sayangnya selama pendahuluan pembelajaran IK belum secara maksimal menyampaikan materi, tugas, maupun mengaitkan materi pada pertemuan selanjutnya dengan pertemuan saat itu. Sedangkan alokasi waktu IK dalam kegiatan ini sudah sesuai dengan RPP.

\section{b. Kegiatan Inti}

Pelaksanaan kegiatan inti di SMA Negeri 1 Surakarta dan Sekolah Indonesia Singapura secara garis besar telah menerapkan konsep pembelajaran Kurikulum 2013, yaitu dengan pemilihan pendekatan, model, dan media yang disesuaikan dengan kondisi siswa serta kelas (Permendikbud Nomor 22 Tahun 2016). Dalam pembelajaran Teks Cerita Ulang/Biografi ini ES dan IK sama-sama menggunkan media audio visual berupa video tokoh biografi. Penggunaan media 
ini dilakukan untuk menarik perhatian siswa sehingga siswa lebih mudah untuk memahami materi yang disampaikan guru.

Meskipun telah menerapkan konsep pembelajaran yang sesuai dengan peraturan, namun implementasi kegiatan inti ini berbeda dengan apa yang dituliskan dalam RPP. Dalam RPP ES seharusnya siswa secara berkelompok melakukan diskusi, sedangkan implementasinya siswa secara individu menjawab soal-soal secar tulis maupun lisan. Dalam kegiatan tersebut siswa secara keseluruhan mendapatkan giliran menjawab pertanyaan. Sedangkan dalam RPP IK, siswa seharusnya melakukan analisis teks, namun implementasinya siswa diarahkan untuk menyusun biografi dan mempresentasikannya di depan kelas. dalam kegiatan tersebut semua siswa mendapat giliran untuk melakukan presentasi dan saling menanggapi presentasi teman.

\section{c. Kegiatan Penutup}

Menurut Permendikbud Nomor 22 Tahun 2016 kegiatan penutup yang harus dilakukan guru bersama siswa baik secara individual maupun kelompok adalah kegiatan refleksi untuk mengevaluasi : (1) seluruh rangkaian aktivitas pembelajaran dan hasil-hasil yang diperoleh untuk selanjutnya secara bersama menemukan manfaat langsung maupun tidak langsung dari hasil pembelajaran yang telah berlangsung; (2) memberikan umpan balik terhadap proses dan hasil pembelajaran; (3) melakukan kegiatan tindak lanjut dalam bentuk pemberian tugas, baik tugas individual maupun kelompok; dan (4) menginformasikan rencana kegiatan pembelajaran untuk pertemuan berikutnya.

Berdasarkan hasil pengamatan Peneliti, kegiatan penutup di SMA Negeri 1Surakarta ES telah memenuhi persyaratan yaitu dengan melakukan kegiatan evaluasi seperti mengajak siswa untuk me-review, memberikan pertanyaapertanyaan untuk mengecek pemahamn siswa, hinga pemberian tugas. Kekurangan ES adalah alokasi waktu yang tidak sesuai dengan RPP, dalam RPP ES harus melakukan kegiatan penutupan selama 30 menit, sedang implementasinya hanya 10 menit.

Kegiatan penutup yang dilakukan oleh IK di Sekolah Indonesia Singapura masih jauh dari kata sesuai. Berdasarkan CLHO-5, CLHO-6, dan hasil wawancara 
dengan siswa, IK memang jarang melakukan kegiatan refleksi seperti kegiatan penutup. Namun dalam kegiatan penutup tersebut peneliti menemukan hal menarik di Sekolah Indonesia Singapura, dimana setiap akhir pembelajaran siswa dan guru tetap menunjukkan kedekatan dan keakraban yang kental. Hal ini ditunjukkan dengan saling bersalaman dan mengucapkan salam.

\section{Penilaian Pembelajaran Teks Biografi dengan Kurikulum 2013 kelas X di SMA Negeri 1 Surakarta dan Sekolah Indonesia Singapura}

Penilaian adalah suatu kegiatan untuk memberikan berbagai informasi secara berkesinambungan dan menyeluruh tentang proses dan hasil yang telah dicapai siswa. Permndikbud Nomor 22 Tahun 2016 menyatakan 3 aspek penilaian dalam Kurikulum 2013 revisi adalah aspek sikap, pengetahuan, dan keterampilan.

Adapun penilaian yang dilakukan di SMA Negeri 1 Surakarta berdasarkan wawancara dalam CLHW-5 dan observasi dalam CLHO-3 dan CLHO-4 ES telah melaksanakan penilaian kepada tiga aspek tersebut, yaitu sikap, pengetahuan, dan keterampilan siswa. Untuk aspek sikap ES mengambil objek pengamatan meliputi keaktivan, minat, penggunaan bahasa selama kegiatan pembelajaran. ES menggunakan instrumen berupa lembar pengamatan/observasi. Kemudian memberikan hasil penilaian sikap dalam bentuk deskripsi. Adapaun berdasarkan CLHW-5, CLHO-3, dan CLHO-4 ES menilai aspek pengetahuan dan keterampilan dengan menggunakan teknik tertulis, tes lisan, serta praktik. Namun dalam penulisan RPP, aspek Keterampilan tidak dituliskan ES secara jelas dan menyeluruh seperti aspek sikap dan penegtahuan. Adapun isntrumen yang digunakan ES adalah soal-soal tanya jawab dan penugasan untuk mempresentasikan jawaban siswa ke depan kelas.

Penilaian di Sekolah Indonesia Singapura selama penerapan Kurikulum 2013 terbaru, IK menggunakan teknik pengamatan/observasi dalam penilaian aspek sikap. Adapun objek yang menjadi pengamatan sikap IK diantaranya seperti minat belajar siswa, keaktivan, penggunaan bahasa, serta kerja sama dan kejujuran. IK menggunakan instrumen berupa lembar pengamatan siswa, dengan menuliskan deskripsi sikap siswa dengan bantuan kode-kode sebagai bentuk hasil penilaian. Penilaian aspek pengetahuan IK menggunakan teknik pemberian soal 
atau pertanyaan untuk dijawab siswa secara individu. Instrumen yang digunakan IK dalam penilaian ini adalah soal-soal yang terdapat dalam buku pegangan guru kemudian diberikan kepada siswa. Selanjutnya dalam aspek keterampilan, IK menggunakan teknik penugasan berupa pembuatan karya, IK menggunakan hasil temuan/karya siswa dan penampilan presentasi siswa sebagai objek penilaian keterampilan. Namun dalam hal ini IK masih belum menerapkan penilaian skor skala 1-100 sebagaiman anjuran pemerintah terbaru di Kurikulum 2013.

Masalah yang Dihadapi dalam Pembelajaran Bahasa Indonesia dengan Kurikulum 2013 kelas X di SMA Negeri 1 Surakarta dan Sekolah Indonesia Singapura

Kurikulum 2013 sudah diluncurkan sejak tahun 2013 dan mengalami revisi pada tahun 2016. Meskipun sudah cukup lama Kurikulum 2013 mewarnai dunia pembelajaran hal ini masih tidak menutup kemungkinan timbulnya permasalahan yang dihadapi oleh guru maupun siswa. Berdasarkan hasil kajian mengenai pelaksanaan Kurikulum 2013 dalam pembelajaran Bahasa Indonesia kelas X di SMA Negeri 1 Surakarta Peneliti telah mengidentifikasi masalah yang diantaranya adalah masalah yang dihadapi guru dan siswa yaitu; a) Guru belum memiliki buku/regulasi sebagai pegangan yang dapat digunakan sebagai acuan untuk memahami dan menyusun RPP yang sesuai dengan Kurikulum 2013 edisi revisi, b) terbatasnya waktu dan tempat untuk melakukan pembelajaran di luar kelas pada materi pembelajaran Teks Biografi, c) siswa mengalami kesulitan dalam memahami dan mengingat materi kaidah kebahasaan pada materi pembelajaran Teks Biografi, d) siswa kurang memiliki motivasi dalam pembelajaran Teks Biografi.

Berdasarkan hasil kajian mengenai pelaksanaan Kurikulum 2013 dalam pembelajaran Bahasa Indonesia kelas X di Sekolah Indonesia Singapura, Peneliti telah mengidentifikasi masalah diantaranya adalah masalah yang dihadapi guru dan siswa yaitu; a) Guru belum memiliki buku/regulasi sebagai pegangan yang dapat digunakan sebagai acuan untuk memahami dan menyusun RPP yang sesuai dengan Kurikulum 2013 edisi revisi, b) terbatasnya waktu untuk mempersiapkan pembelajaran Teks Biografi, c) terbatasnya sumber informasi dan referensi buku untuk materi Teks Biografi, d) siswa belum memahami konsep belajar dengan 
Kurikulum 2013 edisi revisi, e) siswa mengalami kesulitan dalam memahami dan mengingat materi kaidah kebahasaan pada materi pembelajaran Teks Biografi, f) siswa kurang memiliki motivasi dalam pembelajaran Teks Biografi.

Upaya untuk Mengatasi Masalah dalam Pembelajaran Bahasa Indonesia dengan Kurikulum 2013 kelas X di SMA Negeri 1 Surakarta dan Sekolah Indonesia Singapura

Upaya yang dilakukan oleh guru dan pihak sekolah di SMA Negeri 1 Surakarta untuk mengatasi permasalahan yang timbul diantaranya sebagai berikut; (a) penggunaan dan memaksimalkan fungsi alat-alat pendukung proses pembelajaran seperti media belajar dan laboratorium. Hal ini dilakukan pihak guru dalam mengatasi terbatasnya waktu dan tempat untuk mengajar siswa karena guru mengaku tidak memungkinkan mereka untuk menerapkan sistem belajar keluar kelas. Dengan adanya fasilitas yang dimiliki sekolah, guru memaksimalkan fungsi dan peranan alat pendukung pembelajaran, (b) penggunaan strategi pembelajaran yang menarik, menggunakan strategi pembelajaran seperti penyampaian materi dengan media audio visual berupa video tokoh untuk menciptakan suasana belajar yang menarik bagi siswa, (c) penggunaan buku teks terbitan/cetakan lama yang materinya disesuaikan dengan Kompetensi Dasar yang digunakan dalam pembelajaran guna menambah referensi dan sumber belajar bagi guru.

Adapun upaya yang ditemukan Peneliti dari Sekolah Indonesia Singapura dalam mengatasi permasalahan yang ada adalah sebagai berikut; a) penggunaan sumber belajar dari media online dan buku-buku teks terbitan lama. Guru menggunakan sember belajar dari media online dan buku teks terbitan lama yang materi Kompetensi Dasarnya sama dengan yang dibutuhkan. Hal ini dilakukan karena dari pihak sekolah maupun pemerintah sendiri saat itu belum mengeluarkan cetakan buku teks siswa maupun pendamping bagi guru, b) penggunaan strategi pembelajaran yang menarik minat siswa dalam mengikuti dan memudahkan siswa dalam belajar. Penerapan beberapa strategi pembelajaran seperti pendekatan, metode, model, media mapun penggunaan alat yang menarik 
bagi siswa dipilih guru untuk membantu mereka lebih mudah memahami dan mengingat materi ajar, dalam hal ini yang disoroti adalah penggunaan media oleh guru seperti media audio visual berupa video tokoh biografi, c) perencanaan penggunaan kartu hadir siswa. Perencanaan penggunaan kartu hadir siswa menjadi pilihan pihak sekolah dan guru sebagai salah satu langkah tegas guna memacu siswa untuk berangkat ke sekolah, dengan cara ini diharapkan siswa lebih disiplin waktu untuk masuk dan pulang sekolah sesuai jadwal yang berlaku.

\section{SIMPULAN}

Berdasarkan hasil temuan peneltitian, simpulan yang dapat ditarik peneliti adalah; (1) Perencanaan pembelajaran yang dilakukan guru di SMA negeri 1 surakarta dan sekolah indonesia singapura diawali dengan pengkajian silabus terbaru dari pemerintah, namun belum disertai dengan penyusunan RPP yang sesuai dengan konsep kurikulum 2013 terbaru, (2) Pelaksanaan pembelajaran kurang sesuai dengan rpp yang sebelunya ditulis oleh guru, namun secara garis besar telah sesuai dengan Permendikbud nomor 22 tahun 2016, (3) Penilaian pembelajaran telah menerapkan pendekatan otentik sesuai premendikbud nomor 23 tahun 2016, namun di SMANegeri 1 Surakarta penilaian keterampilan masih kurang, dan di Sekolah Indonesia Singapura masih menggunakan penilaian skala 1-10, (4) Masalah yang dihadapi adalah Guru belum memiliki buku/regulasi pegangan sebagai acuan dalam penyususnan RPP sesuai dengan Kurikulum 2013 edisi revisi, keterbatasan sumber belajar, keterbatasan waktu dan tempat, keterbatasan fasilitas dan sarpras, kesulitan siswa dalam memahami dan mengingat materi kaidah kebahasaan dalam materi Teks Biografi,masih cukup rendah pemahaman belajar dengan kurikulum 2013 pada siswa di Sekolah Indonesia Singapura, dan rendahnya motivasi belajar siswa, (5) Upaya yang dilakukan yaitu pihak sekolah dan guru berupaya untuk mengikuti perkembangan terkait kurikulum 2013, penggunaan strategi pembelajaran yang menarik seperti media audio visual berupa video tokoh biografi, penyusunan sistem presensi siswa, dan pemaksimalan fungsi sumber, fasilitas, dan media online yang ada. 
Beberapa saran yang hendak disampaikan peneliti adalah pertama bagi guru; (1) mengikuti dan mencermati perkembangan peraturan pemerintah, (2) menumbuhkan sikap kritis dan kemampuan menyusun strategi pembelajaran, (3) menciptakan suasana pembelajaran yang akrab dan menyenangkan, (4) memberikan motivasi dan pengertian belajar dengan Kurikulum 2013 secara efektif kepada siswa. Bagi sekolah penyelenggaran Kurikulum 2013; (1) membentuk tim pengembang dan pengelolaan kurikulum, (2) mengembangkan dan melengkapi fasilitas sekolah. Pemerintah Pusat agar (1) membentuksyaratsyaratpembelajarandansistemkurikulumdenganmemperhatikankondisilatarbelakan gtiapsekolah, dan (2) melakukan monitoring danevaluasisecaramenyeluruh.

\section{DAFTAR PUSTAKA}

Apandi, Idris. (2016, 17 Januari). Elemen-elemen Revisi Kurikulum 2013. Kompasiana. Diperoleh pada 17 Januari 2016, dari www.kompasiana.com.

Fadlillah, M. (2014). Implementasi Kurikulum 2013 dalam Pembelajaran SD/MI/SMP/MTS, \& SMA/MA. Yogyakarta: Ar-Ruzz Media.

Gunawan, I. (2015). Metode Penelitian Kualitatif: Teori dan Praktik. Jakarta: Bumi Aksara.

Kurniasih, Imas dan Berlin Sani. (2014a). Implementasi Kurikulum 2013 Konsep dan Penerapan. Surabaya: Kata Pena.

Kurniasih, Imas dan Berlin Sani. (2014b). Sukses Mengimplementasikan Kurikulum 2013 Memahami Berbagai Aspek dalam Kurikulum 2013. Surabaya: Kata Pena.

Kurniasih, Imas dan Berlin Sani. (2017c). Revisi Kurikulum 2013 Implementasi Konsep dan Penerapan. Surabaya: Kata Pena

Masjid, Abdul. (2014) Pembelajaran Tematik Terpadu. Bandung: PT Remaja Roesdakarya.

Mulyasa, E. (2014). Pengembangan dan Implementasi Kurikulum 2013. Bandung: PT Remaja Rosdakarya.

Nurjanah, Marjan. (2015). Eksplorasi Hasil Belajar Siswa Kelas X dengan Pendekatan Scientific di Sekolah Indonesia Singapura. Abstrak Hasil 
Penelitian Universitas Pendidikan Indonesia.Bandung: Universitas Pendidikan Indonesia.

Permendikbud Nomor 22 Tahun 2016 Tentang Standar Proses Pendidikan Dasar dan Menengah.

Rumahlatu, Dominggus., Huliselan.E.K., \& Takaria.J. (2016). An Analysis of the Readiness and Implementation of 2013 Curriculum in The West Part of Seram District, Maluku Province, Indonesia (Versi elektronik). International Journal of Environmental \& Science Education, 11 (12) 56625675. Diperoleh pada 12 Januari 2018, dari http://academicpublisher/lookopenaccess/

Yani, Ahmad. (2014). Mindset Kurikulum 2013. Bandung: Alfabeta 